\title{
PROPRANOLOL IN THE MANAGEMENT OF CARDIAC ARRHYTHMIAS DURING HYPOTHERMIA
}

\author{
A. F. D. Cole, M.D., AND J. A. JACOBS, B.A., M.B., B.CH., F.R.C.P.(C)
}

The FIRST DRUg known to have significant specific beta adrenergic receptor blocking properties was dichloro-isoproterenol (DCI). ${ }^{1}$ Black and Stephenson noted that pronethalol, a congener of $\mathrm{DCI}$, produced bradycardia, and suggested its use in cardiac arrhythmias. ${ }^{2}$ Subsequent investigations confirmed the value of pronethalol in certain arrhythmias. ${ }^{3,4}$ The clinical use of pronethalol has been largely curtailed, however, as it has been shown to produce thymic tumours in mice. ${ }^{5}$ Another more potent beta blocker, propranolol (Inderal), has been introduced, which is free of carcinogenic activity, and has been employed in various arrhythmias, with some definite therapeutic results. ${ }^{0-8}$ There are no reports on the use of propranolol against arrhythmias during hypothermia.

\section{Case Report}

Mrs. E. R., 49 years old, was presented with a two-week history of pounding headaches. The remainder of the history was non-contributory. Physical examination revealed a moderately obese woman, weighing $170 \mathrm{lbs}$., and was otherwise unremarkable. A spinal tap revealed xanthochromic cerebrospinal fluid. An electrocardiogram showed sinus rhythm with a small $q$ wave in leads II, III and AVF, and low $T$ waves in II, III, AVF, and the chest leads, indicative of some myocardial damage. Carotid arteriography demonstrated two aneurysms, one in each posterior communicating artery. It was decided to clip the aneurysms, in two operations, and the first was to be performed under moderate hypothermia.

After premedication with $0.6 \mathrm{mg}$. atropine, anaesthesia was induced with thiopentone $250 \mathrm{mg}$, tracheal intubation performed with $100 \mathrm{mg}$. succinylcholine, and anaesthesia maintained with 1 per cent halothane and nitrous oxide and oxygen at flow rates of 5 and 3 litres respectively. The patient was curarized and ventilated with intermittent positive pressure. Surface cooling was begun, and proceeded uneventfully for two hours. However, when the oesophageal temperature reached $33.6^{\circ} \mathrm{C}$. a few ventricular premature beats appeared, persisted for less than five minutes, then subsided spontaneously. Cooling then proceeded uneventfully, and the skull flap was turned.

Three hours after the start of cooling, the oesophageal temperature was $32.3^{\circ}$, pulse 95 , blood pressure 160/90, and active cooling was discontinued. As the temperature continued to fall, multifocal ventricular ectopic beats reappeared and became more frequent. There were also atrial premature beats, runs of nodal tachycardia, and bursts of ventricular tachycardia. This arrhythmia persisted

\footnotetext{
-Department of Anaesthesia, University of Toronto and St. Michael's Hospital, Toronto, Ontario.
} 
unabated for 45 minutes, although there was at no time any significant blood pressure change.

Three hours and 45 minutes after the onset of cooling, with the oesophageal temperature $31.5^{\circ}$, in view of the persisting arrhythmia a total of $0.5 \mathrm{mg}$. of propranolol was administered intravenously, in four doses, over a period of 20 minutes. Within one minute of each dose there was a reduction in the frequency of ectopic beats, and within five minutes of the last dose sinus rhythm was restored and maintained.

The surgery proceeded uneventfully, as did the emergence from hypothermia and anaesthesia, and the postoperative course was unremarkable. Three weeks later, the remaining aneurysm was clipped, this time under nitrous oxide, oxygen, halothane, and curare, with Arfonad-induced hypotension for 20 minutes during the actual clipping. The second anaesthetic was uneventful except for occasional isolated ventricular premature beats which subsided rapidly and spontaneously.

\section{Discussion}

This case illustrates the apparent successful use of propranolol, a beta adrenergic blocking agent, for a severe persistent arrhythmia during moderate hypothermia. In view of the dramatic cessation of the arrhythmia (within minutes of administration of propranolol) after 45 minutes without spontaneous improvement, it is unlikely that the reversion to sinus rhythm was mere coincidence. The core temperature change during the period in question was not striking, and the conditions of ventilation, blood pressure, palpable pulse and anaesthetic agents were all nearly constant, so it is similarly unlikely that the improvement was due to improved cardiac perfusion, oxygenation, or fortuitous withdrawal of toxic agents. The surgery had been interrupted while the arrhythmia persisted, thus removal of noxious surgical stimuli cannot be credited.

Three general courses of action were considered in the management of this arrhythmia. The first was to rewarm the patient, and perform the operation at a later date without hypothermia. The second was to ignore the arrhythmia and proceed with the operation, since there seemed to be no severe haemodynamic defect. The recognized frequency of ventricular fibrillation during hypothermia (particularly in diseased hearts), which is often heralded by ventricular arrhythmias, ruled against this course. Also, the operation was to involve manipulation of the Circle of Willis, a procedure which in itself is capable of precipitating arrhythmias, or aggravating existing ones. ${ }^{9}$

The alternative was to treat the arrhythmia, and once this decision had been made, the choice of agent remained. Propranolol has been shown to be effective, indeed lifesaving, in severe ventricular arrhythmias. ${ }^{B}$ However, the danger of cardiac depression with severe cardiac failure or hypotension in hearts with borderline function subjected to beta adrenergic blockade has been stressed.? The administration of propranolol may also decrease coronary blood flow by blocking coronary beta vasodilator and unmasking alpha vasoconstrictor responses to catecholamines. ${ }^{10}$ 
Recognizing these risks, and the generally depressed inactivation of drugs during hypothermia, it was elected to administer propranolol in increments of $0.1 \mathrm{mg}$., monitoring electrocardiogram, pulse, and blood pressure closely. The total dose used was $0.5 \mathrm{mg}$. ( $0.006 \mathrm{mg} . / \mathrm{kg}$.)

Ventricular fibrillation, frequently preceded by other ventricular arrhythmias, is said to be rare at temperatures above $28^{\circ} \mathrm{C}$, but it is generally conceded that it is more likely to occur in diseased hearts. The aetiology and pathogenesis of these arrhythmias are obscure, and no one method of treatment or prophylaxis has proved universally valuable. ${ }^{11}$

Several studies implicate the action of catecholamines or sympathetic nervous system activity in the production of ventricular fibrillation. Shumacker et al. noted that bilateral sympathetic denervation of the heart and ganglionic blockade with Arfonad provided some protection against ventricular fibrillation during hypothermia. ${ }^{12}$ Berne demonstrated that administration of epinephrine during hypothermia may precipitate ventricular fibrillation..$^{13}$ Galindo showed some protection from ventricular fibrillation by total epidural anaesthesia. ${ }^{14}$

The adrenal medullary secretion of catecholamines is unchanged or depressed under hypothermia, ${ }^{15}$ however, the action of epinephrine is enhanced, presumably by inhibition of its metabolic degradation. ${ }^{16}$ All these studies would appear to implicate catecholamines in the pathogenesis of at least some cases of hypothermic ventricular fibrillation, and this would provide a rationale for the use of a beta adrenergic blocker. (It is of interest that an alpha blocker, dibenamine, was used without success in the attempted prophylaxis of ventricular fibrillation. $)^{17}$ However, Covino demonstrated that sympathomimetic drug infusion may actually exert a protective effect against hypothermic ventricular fibrillation. ${ }^{18}$

Certainly, no sweeping conclusions may be drawn as to the treatment of arrhythmias arising during hypothermia, since the mechanism of production is still obscure; however, the results in this case suggest that propranolol in appropriate doses may be of value in certain instances.

\section{SUMMARY}

This is a report of a case in which beta adrenergic blockade apparently cured a troublesome cardiac arrhythmia during moderate hypothermia. The total dose used was considerably smaller than has been reported during anaesthesia.

\section{RÉSUMÉ}

La fibrillation ventriculaire, souvent précédée par d'autres arythmies ventriculaires, survient au cours de l'hypothermie, mais l'on dit que la chose est rare a des températures au-dessus de $28^{\circ} \mathrm{C}$. En général, on est d'avis que cela peut survenir sur des coeurs malades. L'étiologie et la pathogénie de ces arythmies demeurent obscures et il n'y a pas de méthode de traitement ou de prophylaxie qui s'est avérée universellement précieuse.

De nombreuses études ont inclus l'action des catécholamines et l'activité du sympathique comme facteurs dans l'apparition de la fibrillation ventriculaire. 
Shumaker et ses associés ont observé que la sympathectomie bilatérale du coeur et le blocage ganglionnaire avec l'Arfonad procurent une certaine protection contre la fibrillation ventriculaire au cours de l'hypothermie. Berne a démontré que l'administration d'épinéphrine au cours de l'hypothermie peut occasionner une fibrillation ventriculaire. Galindo a démontré qu'une anesthésie épidurale totale offrait une certaine protection contre la fibrillation ventriculaire.

Au cours de l'hypothermie, la sécrétion médullaire surrénalienne de catécholamines demeure inchangée ou est diminuée. Toutefois, l'action de l'épinéphrine est exagérée par inhibition de sa dégradation métabolique, nous présumons. Toutes les études, semble-t-il, s'accordent à accuser les catécholamines comme facteur causal dans la pathogénie d'au moins quelques cas de fibrillation ventriculaire sous hypothermie et cela pourrait justifier l'usage de bloqueurs beta adrénergiques.

Nous rapportons un cas où, au cours d'une hypothermie à des températures entre $32.3^{\circ} \mathrm{C}$. et $31.5^{\circ} \mathrm{C}$., sont apparus des battements ventriculaires ectopiques à multiples foyers, des battements auriculaires prématurés, des salves de tachycardie nodale et des épisodes de tachycardie ventriculaire et le tout sans changement durant 45 minutes. Nous avons envisagé trois lignes de conduite générale dans le traitement de cette arythmie. La première a été de réchauffer le malade et de remettre l'opération à plus tard et sans hypothermie. La seconde a été de ne pas tenir compte de l'arythmie et d'opérer puisque l'hémodynamique ne semblait pas modifiée de façon importante. Le propranolol s'est avéré efficace dans les arythmies ventriculairs graves. Toutefois, on a signalé le danger de dépression cardiaque et d'insuffisance cardiaque grave ou d'hypotension sur des coeurs au rendement limite lors de l'usage de bloqueurs beta adrenergiques. L'administration de propranolol peut aussi diminuer le débit coronarien en bloquant les beta vasodilatateurs coronariens et en libérant les réponses des alpha vasoconstricteurs aux catécholamines.

Chez ce malade, on décide d'administrer du propranolol à raison de $0.1 \mathrm{mg}$. avec un moniteur de l'électrocardiogramme du pouls et de la pression artérielle. La dose totale a atteint $0.5 \mathrm{mg}$, alors le rythme nodal est apparu et a persisté durant toute lopération. Ce cas nous laisse croire que le propranolol, à doses appropriées en certaines occasions, au cours d'hypothermie, peut faire disparaittre les arythmies.

\section{REFERENCES}

1. Power., C. E. \& Szater, I. H. Blocking of Inhibitory Adrenergic Receptors by a Dichloro Analogue of Isoproterenol. J. Pharmacol. \& Exper. Therap. 122: 480 (1958).

2. BLACK, J. W. \& STEPHENSON, J. S. Pharmacology of a New Adrenergic Beta-Receptor Blocking Compound, Nethalide. Lancet $t: 311$ (1962).

3. Srock, J. P. P. \& Dale, N. Beta-Adrenergic Receptor Blockade in Cardiac Arrhythmias. Brit. M. J. ii. 1230 (1963).

4. Johnstone, M. Beta-Adrenergic Blockade with Pronethalol during Anesthesia. Brit. J. Anaesth. 36: 224 (1964).

5. PAGET, C. E. Carcinogenic Action of Pronethalol. Brit. M. J. it: 1266 (1963).

6. Sloman, J. G.; Robinson, J. S.; \& McLean, K. H. Inderal in Persistent Ventricular Fibrillation. Brit. M. J. I: 895 (1965).

7. Besterman, E. M. M. \& Frimlander, D. H. Clinical Experiences with Propranolol. Postgrad. M. J. $41: 479$ (1965). 
8. Joknstone, M. Propranolol (Inderal) during Halothane Anesthesia. Brit. J. Anaesth. 38: 516 (1966).

9. Poox, J. L. \& Krsster, L. A. Mechanisms and Control of Centrally Induced Cardiac Irregularities During Hypothermia. J. Neurosurg. 15: 52 (1958).

10. Parratt, J. R. \& Grayson, J. Myocardial Vascular Reactivity after Beta Adrenergic Blockade. Lancet $i$ : 338 (1966).

11. BoвA, A. Hypothermia for the Neurosurgical Patient. 1st ed., Springfield, Illinois: Thomas (1960).

12. Shumacker, H. B.; Riberi, A.; Boone, R. D.; \& KajIEURr, H. Ventricular Fibrillation in the Hypothermic State: IV. The Role of Extrinsic Cardiac Innervation. Ann. Surg. 143: 223 (1956).

13. Berne, R. M. The Effect of Immersion Hypothermia on Coronary Blood Flow. Circ. Res. 2: 236 (1954).

14. Galindo, A. \& Sprouse, J. H. The Influence of Epidural Anesthesia on Cardiac Excitability in Profound Hypothermia. Canad. Anaesth. Soc. J. 11: 614 (1964).

15. Hume, D. M. \& EgDami, R. H. Effect of Hypothermia and of Cold Exposure on Adrenal Cortical and Medullary Secretion. Ann. N.Y. Acad. Sci. 80: 435 (1959).

16. Garb, S. \& PENNA, M. Relationship of Temperature to Sensitivity of the Mammalian Auricle to Sympathomimetic Amines. J. Appl. Physiol. 9: 431 (1956).

17. Covino, B. G.; Charleson, D. A.; \& D'Amato, H. E. Ventricular Fibrillation in the Hypothermic Dog. Am. J. Phys. 178: 148 (1954).

18. Covino, B. G. \& D'Amato, H. E. Mechanism of Ventricular Fibrillation in Hypothermia. Circ. Res. 10: 148 (1962). 